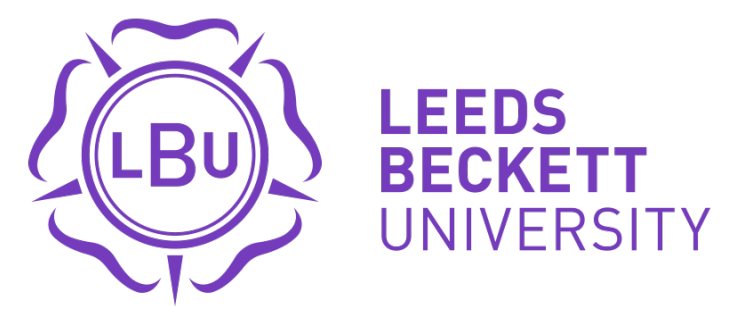

Citation:

Gifkins, J (2016) R2P in the UN Security Council: Darfur, Libya and beyond. Cooperation and Conflict, 51 (2). 148 - 165. ISSN 0010-8367 DOI: https://doi.org/10.1177/0010836715613365

Link to Leeds Beckett Repository record:

https://eprints.leedsbeckett.ac.uk/id/eprint/2189/

Document Version:

Article (Accepted Version)

This research was supported by a grant from the Graduate School International Travel Award and a grant from the School of Political Science and International Studies, both from the University of Queensland.

The aim of the Leeds Beckett Repository is to provide open access to our research, as required by funder policies and permitted by publishers and copyright law.

The Leeds Beckett repository holds a wide range of publications, each of which has been checked for copyright and the relevant embargo period has been applied by the Research Services team.

We operate on a standard take-down policy. If you are the author or publisher of an output and you would like it removed from the repository, please contact us and we will investigate on a case-by-case basis.

Each thesis in the repository has been cleared where necessary by the author for third party copyright. If you would like a thesis to be removed from the repository or believe there is an issue with copyright, please contact us on openaccess@leedsbeckett.ac.uk and we will investigate on a case-by-case basis. 


\title{
R2P in the UN Security Council: Darfur, Libya and Beyond
}

\author{
Jess Gifkins
}

\begin{abstract}
It has been argued that consensus on the responsibility to protect (R2P) was lost in the UN Security Council as a result of the NATO-led intervention in Libya in 2011. This argument assumes that there was more agreement on R2P before the Libyan intervention than there was afterwards. Yet a close examination of the Security Council's use of language on R2P shows the opposite: R2P was highly contentious within the Security Council prior to the Libyan intervention, and less so afterwards. Not only has the Council used R2P language more frequently since 2011, but also negotiating this language has become quicker and easier. To demonstrate this I compare negotiations on Darfur with deliberations during and after the Arab Spring. Resolution 1706 on Darfur was the first time the Security Council referred to R2P in a country-specific resolution - and indeed it was the only country-specific resolution to refer to R2P before 2011 - making it an apt point of comparison. Via focused analysis on how the language used in Security Council resolution evolves over time, this article demonstrates that the Council has found 'agreed language' on R2P that is acceptable to members, both for thematic resolutions and country-specific resolutions. Language on R2P in Security Council resolutions has shifted from contentious to commonplace.
\end{abstract}

\section{Keywords}

Responsibility to Protect, United Nations Security Council, resolutions, language, decision-making

\section{Introduction $^{\mathrm{i}}$}

Within weeks of the conflict escalating in Libya in 2011 the UN Security Council adopted Resolutions 1970 and 1973. These resolutions were unusually quick and decisive. The two resolutions referred the situation in Libya to the International Criminal Court, created an arms embargo and targeted sanctions, authorised the use of force, and created a no-fly zone over Libya. These two resolutions, and particularly 1973 which 
authorised the no-fly zone, have provoked intense debate in the years that followed. Significantly, Resolution 1973 marked the first time the Security Council authorised the non-consensual use of force for the protection of civilians against a functioning state (Bellamy and Williams, 2011: 825; Glanville, 2013: 325). Given this, it represents a decisive example of implementing the coercive aspects of the responsibility to protect (R2P). The outcome of regime change in Libya has opened up debates over the implementation of R2P.

Many have argued that there has been a backlash against R2P after the Libyan intervention. For example, Gareth Evans argued that ‘consensus fell away’ after Libya (2012). Likewise, Ramesh Thakur has said that the international consensus on R2P has been damaged by the Libyan intervention (2013: 72). Graham Cronogue took this a step further and argued 'The legacy of NATO's overreach in Libya will make Russia and China extremely hesitant to approve the Responsibility to Protect in the future' (2012: 151). While NATO’s actions in Libya, particularly on regime change, have been contentious these arguments assume that there was more consensus on R2P in the Security Council before the Arab Spring than there was afterwards. Some have challenged this argument by showing that the Security Council used R2P in resolutions more often in the two years after Libya than it had used it prior to 2011 (Bellamy, 2014: 26; Weiss, 2014: 10). Frequent use of R2P language is part of the change, but the ease and speed with which R2P language has been included in Council resolutions since Libya also represents a significant shift. 
To demonstrate the depth of this change, this article draws on the case of Darfur. Libyan Resolution 1970 was the second country-specific resolution to include language on R2P, while Darfur Resolution 1706 was the first. It took six months to negotiate Resolution 1706 on Darfur in 2006, and language on R2P proved to be one of the most difficult aspects. The following year, there was insufficient agreement to refer to R2P again in a resolution on Darfur, and this language was removed from an early draft. This contrasts strongly with the period from 2011 onwards, beginning with Libya, where the Council has routinely included language on R2P in resolutions. These negotiations have been quick and language on R2P has not been a major obstacle in the negotiations. Language on R2P has become more acceptable to Security Council members over time, and the Libyan resolutions in 2011 mark the turning point.

This article focuses on the way language on R2P has been used in Security Council resolutions and how it has changed over time. Resolutions are the strongest form of decision the Security Council makes, and can be legally binding, but this article analyses the politics of drafting resolutions rather than their legal effects. ${ }^{\text {ii }}$ While there is literature which discusses the language of specific Council resolutions, there have been few sustained studies on the language in Security Council resolutions more broadly. ${ }^{\text {iii }}$ To analyse the politics of language in Security Council negotiations - and R2P language more specifically - this article proceeds in two parts. The first section discusses the significance of language within the Security Council, which can be resistant to innovation, but new language can become routinized over time. The second section takes a chronological approach to the Security Council's use of language on R2P in resolutions, 
divided into three phases of the Council's engagement with R2P: from the early stages of R2P in 2001 to 2006; 2007-2010 when R2P was rarely cited; and 2011-2014 with regular language on R2P from the Libyan resolutions onwards. In doing so I show that language on R2P was highly divisive and rarely used by the Council until 2011, and it has been used more frequently since and negotiations have been easier and quicker.

\section{Security Council negotiations and language}

The factors involved in individual Security Council decisions are myriad, so to evidence change we should look for broader trends in how the Council engages with situations of mass atrocity crimes (Bellamy, 2015: 98-102). Looking at shifts in language is one way to show these broader trends. As argued by Fierke, rather than asking whether language is important in international politics, we should ask how and why language is important (2002: 331 and 351). There are three key reasons why language used in Security Council resolutions is important to the process of decision-making: language is not static and evolves as shared understandings change; the wording of resolutions informs future resolutions; and repetition of language is a form of reaffirmation. This section unpacks the implications of these three aspects of decision-making, before turning to language on R2P more specifically.

First, the interpretation and use of language in the Security Council is not static and reflects a negotiated balance of what was acceptable to members at a particular moment in time. The very scope of the Council's mandate - to maintain international peace and security - has been interpreted and reinterpreted over time, expanding the 
Council’s work into new areas (Yamashita, 2007). Resolution 688 on Iraq in 1991, for example, represented an evolution in the Council's practice by determining that the transboundary effects of internal repression could constitute a threat to international peace and security (Wheeler, 2000: 139-171). This reinterpretation of what constituted an 'international threat' enlarged the scope of the Security Council's mandate, via shared interpretations of language. Some states expressed strong concerns about the precedent effects of Resolution 688 at the time, however there was sufficient support within the Council for this evolution to occur (Stromseth, 1993: 86-88). The language in resolutions therefore represents a 'snapshot' showing the political compromise that was widely supported by Security Council members at a given point in time.

Second, drafting resolutions is both political and routine: innovation in language can be intensely political, and yet repeated language can become routine over time. Use of language on the protection of civilians illustrates this pattern of behaviour. As explained by Holt et al, language on the protection of 'civilians under imminent threat of physical violence’ was originally negotiated for a peacekeeping mandate in Sierra Leone in 1999 and was carefully caveated as Council members recognised the precedent effects of this innovation. Since then however, it has become standard phrasing in peacekeeping mandates for different conflicts (2009: 36-47). This is because Security Council members value 'previously agreed language' as it is easier to find agreement on language which states have accepted in the past (Author Interview, 2011b; Dunne and Gifkins, 2011: 523). The language used in previous resolutions becomes the starting point for future negotiations. Indeed, as Neumann (2007) argues, the language used in foreign policy 
decision-making has a particular inertia and tendency towards repetition. ${ }^{\text {iv }}$ The negotiated wording of resolutions shapes future deliberations as Council members value precedent in resolutions. $^{\mathrm{v}}$

Third, repeated use of phrases in Security Council resolutions is not simple automation, devoid of meaning: repetitive practices involve reaffirmation of shared meanings (Adler and Pouliot, 2011: 17). As explained by Neumann, when drafting foreign policy documents: 'the policy had to be repeated, if not it would be weakened' (emphasis in original 2007: 190). This was the approach taken by an official involved in the early R2P negotiations - that R2P language needed to appear in Security Council resolutions, otherwise it would seem that the Council was not serious about R2P (Author Interview, 2011a). Repetition of language in resolutions is both a reflection of the social environment at a given point and also shapes the future resolutions, given the preference for 'previously agreed language'.

The language that appears in Security Council resolutions - whether innovative or repetitive - is the end result of multilateral negotiations at the highest level. When analysed in conjunction with other sources and statements, this language can offer insight into the informal processes by which decisions were reached. The use of R2P language in Security Council resolutions shows that the Council discusses R2P regularly in their internal negotiations, both in relation to specific conflicts and broader thematic issues. Language on R2P in Security Council resolutions demonstrates this pattern of early resistance through to broad acceptance. Early uses of R2P language in Council resolutions in 2006 were strongly resisted and only possible because it was championed 
by activist states inside the Council. This was followed by a period from 2007 to 2010 when using R2P language was too difficult politically and advocates in the Council accepted the political realities. The use of R2P language became routinized and repetitive from 2011 onwards. In recent years R2P has become 'part of the world's diplomatic language’ (Welsh, 2013: 378).

In the case of R2P this will not lead to automaticity in the way the Council responds to crises, given the case-by-case nature of the R2P agreement and the political nature of the Council (on this see Brown, 2003; Welsh, 2013). However, framing situations in relation to R2P helps promote the 'responsibility to consider' how best to respond to mass atrocity crimes, which Welsh shows is a key strength of R2P (emphasis in original 2013: 368). R2P has become a 'commonly accepted frame of reference’ within international politics through which states consider their responses to mass atrocity crimes (Bellamy, 2011b: 1). Regular inclusion of R2P language in Security Council resolutions demonstrates that $\mathrm{R} 2 \mathrm{P}$ is a regular feature of the internal negotiations within the Council. While R2P advocates clearly recognise that R2P will only ever be one aspect of the Council's decision-making (Bellamy, 2015: 72; Welsh, 2013; 387-389) the regular inclusion of R2P within the Council's internal deliberations and resolutions shows that Council members are considering their responses within the remit of R2P.

\section{$\mathbf{R} 2 \mathbf{P}$ in Security Council resolutions}

The UN Security Council has primary responsibility for maintaining international peace and security, so resolutions regularly include language on the responsibilities of parties 
to a conflict and on the protection needs of populations. Given this, we need a way to ascertain when the Security Council is referring to the 'responsibility to protect' populations from genocide, war crimes, ethnic cleansing and crimes against humanity as outlined at the 2005 World Summit - and when they are discussing broader protection responsibilities. Similar to Morris (2013: 1267) and the Global Centre for the Responsibility to Protect (2014a), I consider three different forms of language to constitute a reference to R2P by the UN Security Council. First and most explicitly, I consider invocations of paragraphs 138 and 139 of the 2005 World Summit outcome document. Second, I consider the phrases 'responsibility to protect' and 'responsibility for the protection'. Third, I consider the phrase 'responsibility of [government] to protect'. Since the term 'responsibility to protect' was coined as the title of the 2001 ICISS report, I take 2001 as the starting point for my analysis which goes until the end of $2014 .^{\mathrm{vi}}$

There have been three distinct phases of engagement with R2P by the UN Security Council. First, between 2001 and 2006 R2P language was highly contentious and rarely used. Prior to the 2005 World Summit, there were two resolutions on Darfur which used R2P language in relation to mass atrocity crimes. This suggests that some individual Council members were becoming engaged with R2P at this time, but without formal agreement on what R2P meant to the UN as a whole. Once the UN General Assembly endorsed R2P in 2005 there was a push within the Council to include R2P in resolutions which was met with considerable resistance, and only occurred in three resolutions in 2006. Second, between 2007 and 2010 R2P only appeared in one Security 
Council resolution. Annual debates on R2P in the UN General Assembly began in 2009, along with annual reports on R2P from the UN Secretary-General (UNSG), which helped to foster shared understandings on R2P and how it can be implemented (Bellamy, 2011a: 26-50). For example, the 2014 debate was characterised by stronger support for R2P and a focus on how it can be implemented (Global Centre for the Responsibility to Protect, 2014b). Attempts by states to 'misapply' R2P to the cases of Iraq, Cyclone Nargis and South Ossetia also helped to clarify the meaning and scope of the concept (Badescu and Weiss, 2010). This period was instrumental in building support and understanding on R2P. Third, from 2011 to 2014, beginning with Libya, the Council's references to R2P in resolutions increased sharply. After only using R2P language once in the four years prior to 2011, the Council referred to R2P in 26 resolutions between 2011 and 2014. The following section unpacks these three phases of engagement with R2P.

Early steps in the Security Council: 2001-2006

Prior to the 2005 World Summit, there were two resolutions on Darfur which included language and statements on R2P. ${ }^{\text {vii }}$ These examples are caveated, however, as there was no agreed meaning on R2P within the UN prior to 2005. In September 2004 Resolution 1564 on Darfur recalled that 'the Sudanese Government bears the primary responsibility to protect its population' (UN, 2004c: 2). It has been argued that the use of this language prior to the 2005 World Summit was not connected to R2P (Loiselle, 2013: 331-332). However, there is evidence to suggest a link between the use of this phrase on Darfur and the ICISS report. First, by the time Resolution 1564 passed, there had been links made 
between the situation in Darfur and the ICISS report by UNSG Kofi Annan and by the International Crisis Group (Evans, 2004; UN, 2004d). This shows that there were highlevel discussions and diplomacy linking Darfur and R2P, prior to the 2005 agreement. Second, in the statements after the vote for Resolution 1564 one Security Council member, the Philippines, clearly invoked language from the ICISS report in their statement (Williams and Bellamy, 2005: 27). Echoing the ICISS report, the Ambassador to the Philippines said 'A State has the responsibility to protect its citizens, and, if it is unable or unwilling to do so, the international community — the Security Council — has the moral and legal authority to enable that State to assume that responsibility' (UN, 2004a: 12). By the time Resolution 1564 passed there had been connections made between Darfur and the ICISS version of R2P, both inside and outside the Security Council. This suggests that the phrasing in Resolution 1564 may have had a deliberate connection to the ICISS report, although without an agreed understanding on the scope of R2P.

This pattern was repeated two months later in November 2004. Resolution 1574 on Darfur and southern Sudan included references to R2P in the text of the resolution and in statements made after the vote. The resolution recalled 'the primary responsibility of the Sudanese Government to protect its population’ (UN, 2004e). Again, some statements made after the vote suggested a connection to the ICISS report. The United Kingdom (UK) and the Netherlands made statements on the responsibility of the Sudanese government to provide protection for civilians (UN, 2004b). The inclusion of R2P language in these two resolutions, and the statements made by members, suggests 
that individual Council members were becoming engaged with the ICISS version of R2P during 2004.

This needs to be carefully caveated, however, as there was no formal agreement on $\mathrm{R} 2 \mathrm{P}$ at this time, and debates over the scope and meaning of $\mathrm{R} 2 \mathrm{P}$ were taking place in parallel leading up to the 2005 World Summit. The Council's engagement with R2P after the World Summit can be explicitly linked to the agreed meaning of R2P, so Table 1 shows uses of R2P in resolutions from the World Summit until the end of 2014.

\section{Table 1 goes here}

Following the 2005 World Summit, the Security Council's first use of R2P in a resolution was neither thematic nor country-specific but regional on the Great Lakes region. Resolution 1653 underscored that 'governments in the region have a primary responsibility to protect their populations' (UN, 2006f: 3). Statements made at the time of the vote show that some Council members and other participants had the World Summit version of R2P in mind when drafting this resolution. Slovakia and Denmark, who were both members of the Security Council at the time, discussed R2P in statements prior to the vote (UN, 2006a: 18 and 20). Canada and Norway also participated in this meeting and both referred to R2P, and Canada explicitly cited the World Summit agreement (UN, 2006b: 2 and 46).

Following these early steps, it took six months of difficult negotiations for the Security Council to formally endorse the World Summit agreement on R2P, highlighting 
how resistant the Security Council can be to innovations in language. This occurred in a thematic resolution on the protection of civilians in armed conflict in April 2006. The states who wanted to promote R2P - particularly the UK and France - worked hard to secure language on R2P against considerable resistance. Resolution 1674 specifically recalled 'paragraphs 138 and 139 of the 2005 World Summit Outcome Document regarding the responsibility to protect populations from genocide, war crimes, ethnic cleansing and crimes against humanity' (UN, 2006d: 2). The Security Council's engagement with R2P at this time was far from inevitable. The UK circulated an early draft of Resolution 1674 in November 2005 - six months prior to the adoption of the resolution - which included language on R2P (Security Council Report, 2005). Early in these negotiations there was strong resistance in the Council from China and Russia, while the UK, France and Denmark led the drive towards the resolution (Security Council Report, 2006a). Reaffirming the commitment to R2P was a priority for the UK and France, and the UK in particular used bilateral negotiations with other permanent members of the Council to advocate for support (Security Council Report, 2006c). China agreed to the inclusion of R2P in the resolution in March 2006 - as long as it was the same language used at the World Summit - and Russia was the last permanent member to agree to endorse R2P in the Council (Security Council Report, 2006c). While Resolution 1674 was the first explicit endorsement of the R2P paragraphs by the Security Council, the inclusion of R2P in this resolution was so controversial that a think-tank Security Council Report - speculated afterwards that members might be unwilling to 
engage with R2P again for some time (2006b). Instead, the Council referred to R2P again only months later, but with similar levels of difficulty.

R2P remained highly contentious in the Security Council in 2006. Resolution 1706 on Darfur authorized the transition from African Union peacekeeping to UN peacekeeping in August 2006. This resolution was the first time the Security Council referenced R2P in a country-specific resolution. In the preamble of Resolution 1706, the Security Council recalled Resolution '1674 (2006) on the protection of civilians in armed conflict, which reaffirms inter alia the provisions of paragraphs 138 and 139 of the 2005 United Nations World Summit outcome document' (UN, 2006e: 1). For the UK it was important that the Security Council used R2P soon after Resolution 1674 to demonstrate seriousness about the concept, and again it was the UK and France who particularly wanted R2P included in Resolution 1706 (Author Interview, 2011a). The UK initially tried to include the full paragraphs of the World Summit outcome document in Resolution 1706 but during negotiations this was bargained down to a reference to the relevant paragraphs (Author Interview, 2011b; Author Interview, 2011c). Resolution 1706 took six months to negotiate, with R2P as one of the most contentious aspects of the negotiations.

Given that including R2P in Resolution 1706 was so difficult, it is worth elaborating on the negotiation process and how it became possible. In 2006 there were political and financial pressures for a transition from African Union peacekeeping in Darfur to UN peacekeeping (Hamilton, 2011: 74-82). Peacekeeping relies on the consent of the host state, which is usually obtained in advance, yet the government of Sudan had 
stated repeatedly during 2006 that it did not give this consent (for discussion see Gifkins, 2013: 112-113). To reflect the need for consent, China wanted standard language of 'with the consent of' the Sudanese government to be included in the resolution (UN, 2006c: 5). China also did not want R2P included in the resolution (Author Interview, 2011c). It was important to the UK that the resolution included R2P, so the UK proposed a trade to China whereby R2P stayed in the resolution in exchange for language on consent (WikiLeaks, 2006). This was complicated by the position of the United States (US) who did not want language on consent in the resolution, given that there was no consent at the time of drafting, and they did not want it to appear that Khartoum could veto the proposal (Author Interview, 2011c). The UK proposed the unusual language of 'invites the consent' which was permissible for both China and the US (Author Interview, 2011a). With the UK actively championing R2P, 1706 became the first resolution where the Security Council had applied R2P to a country since its general endorsement in April 2006.

R2P was highly disputed in Resolution 1706 and took six months to find agreement, even then with abstentions from China, Qatar, and Russia. Indeed, a participant involved in these negotiations said that R2P was the most contentious part of Resolution 1706 (Author Interview, 2011c). Although it represented the first time a country-specific resolution had included R2P, it has been described as one of the 'worst Security Council resolutions ever' as it mandated legally binding peacekeeping, but could not be implemented (Lynch, 2010). The legacy of this resolution is significant then, as it increased the difficulty of using R2P language in later resolutions. 
R2P in the background: 2007-2010

Following from these experiences, the Security Council was reluctant to refer to R2P from 2007 to 2010 - indeed it only appears in one resolution during this period. This was Resolution 1894 on the protection of civilians in armed conflict, which included a similar statement to thematic Resolution 1674 and reaffirmed the paragraphs of the World Summit outcome document on R2P, but unlike the earlier resolution, R2P was included in the preamble rather than the operative paragraphs (UN, 2009). As a US State Department official noted, it was easier to negotiate a reference to R2P into the preamble of a resolution than into an operative paragraph (Author Interview, 2011c). Also during this period the Security Council was unable to find agreement on referring to R2P in further resolutions on Darfur. The negotiations towards Resolution 1769 on Darfur in 2007 illustrate how politically charged R2P was for the Security Council during this period.

The UK tried to include R2P in Resolution 1769 on Darfur but there was resistance from both China and Sudan. The transition to UN peacekeeping in Darfur, authorised by Resolution 1706, could not be implemented without the consent of the government of Sudan, which it refused to give, thwarting implementation of the resolution. Instead, a compromise was brokered for a hybrid peacekeeping force between the UN and the AU, authorised under Resolution 1769 in July 2007. An early draft of this resolution included a reference to paragraphs 138 and 139 of the World Summit outcome document, like the previous resolution on Darfur (WikiLeaks, 2007). The UK 
wanted to include R2P in the resolution, but this was too controversial for China and for the government of Sudan and it was removed during negotiations (Author Interview, 2012). Instead, Resolution 1769 cited Resolution 1674 without reference to paragraphs 138 and 139 of the World Summit outcome document (UN, 2007: 1).

This negotiation illustrates how difficult it was for the Security Council to include language on R2P during this period. Indeed, supporters of R2P within the Council were working from the assumption that it was better not to reopen debate on R2P in the Council at this time (Security Council Report, 2007). This level of difficulty was also reflected in Resolution 1814 on Somalia in 2008, which referred to thematic Resolution 1674, but without an explicit link to R2P (Strauss, 2009: 305). Thus, the period from 2007-2010 was characterised by resistance to R2P language from some Council members, and supporters of R2P accepted the political sensitivities of the time.

\section{Libya and beyond: 2011-2014}

The period from 2011 to 2014 has seen a dramatic increase in usage of language on R2P by the Security Council (see Table 1). During this period the Security Council has referred to R2P in country-specific resolutions on Libya, Cote d'Ivoire, South Sudan, Yemen, Mali, Somalia, the Central African Republic and Syria. It has also been cited in thematic resolutions on small arms and light weapons, genocide, the prevention of armed conflict, and peacekeeping operations. While it has been suggested that the Security Council became more sceptical of R2P after NATO’s intervention in Libya, in fact Resolutions 1970 and 1973 on Libya mark the turning point where the Council began to 
refer to R2P regularly in relation to specific conflicts. Indeed, as noted by Bellamy 'the Security Council has proven more willing to use RtoP in relation to specific situations than it was prior to Libya...Rather than running from a delegitimised RtoP, the Council has embraced the principle post-Libya as it never had before' (2014: 39). In this period the Security Council has referred to R2P more regularly in relation to both specific conflicts and thematic issues.

It is not simply the frequency of R2P in Security Council resolutions that is striking; it is also the comparative ease with which language on R2P is included. Resolutions 1674 and 1706 in 2006 each took six months of negotiations, with R2P as one of the most difficult aspects of both resolutions. Whereas from 2011 language on R2P has been quicker and easier to negotiate for both thematic resolutions and countryspecific resolutions. For example, Resolution 2109 in 2013 - which referenced South Sudan's primary responsibility to protect - was negotiated in less than two weeks with relative ease (Security Council Report, 2013b). Likewise, Resolution 2139 which referred to the Syrian government's responsibility to protect, took two weeks of negotiations. There was some resistance from Russia on including R2P language in relation to Syria (Security Council Report, 2014a), but the language on R2P remained in the resolution and Russia voted affirmatively without expressing any concern about R2P in its statement after the vote (UN, 2014a). Using R2P language in relation to specific cases became easier and quicker during this period.

The pattern of both ease and speed is reflected in thematic resolutions as well. The text for the first resolution on small arms and light weapons was drafted in less than 
three weeks. Security Council Report noted that 'Council members differed on a number of issues along traditional dividing lines' including R2P, but language on women peace and security was more challenging in these negotiations than R2P (2013a). Likewise, Rwanda circulated a concept note to mark the twentieth anniversary of the Rwandan genocide, and the Security Council adopted a resolution two weeks later which reaffirmed paragraphs 138 and 139 of the World Summit outcome document (UN, 2014b). Rwanda engaged in bilateral negotiations on language for this resolution, and 'negotiations appear to have gone relatively smoothly’ (Security Council Report, 2014b). These examples stand in stark contrast to the challenging negotiations in 2006 which took a considerable diplomatic investment by the UK and France and took six months of negotiations to reach sufficient consensus.

The key exception to this pattern of quick and easy inclusion of R2P in resolutions has been Syria. Resolutions on Syria have proved very challenging for Council members, but the presence of R2P language does not seem to have been the determining factor. A draft resolution in early 2011 condemned human rights abuses in Syria and recalled the Syrian government's responsibility to protect, but proved too controversial and was not put to a vote (see Gifkins, 2012: 382). In October 2011, a draft resolution was put to a vote in the Council which referred to the Syrian government's responsibility to protect and was vetoed by China and Russia, with abstentions from Brazil, India, Lebanon and South Africa (UN, 2011c). Russia made a statement after the vote that it was 'alarmed by statements that compliance with Security Council resolutions on Libya in the NATO interpretation is a model for the future actions of NATO in implementing the 
responsibility to protect' (UN, 2011b: 4). In this statement, Russia made clear links between Syria and its concerns over the implementation of R2P in Libya. Bellamy has suggested that this link may be somewhat spurious as Russia has been 'inconsistent at best' in linking these two cases and Russia had expressed similar concerns over international coercion in earlier cases of Kosovo and Darfur (2014: 26 and 31). Russia also voted affirmatively for some subsequent resolutions on Syria which contained similar R2P language, suggesting that the language of R2P was not the determining factor (see Table 1).

On Libya, there has been considerable academic discussion on the 'pillar one' language in Resolutions 1970 and 1973 which were framed as the Libyan authorities’ responsibility to protect (UN, 2011d; 2011e) rather than as 'pillar three' international responsibilities (see for example Hehir, 2016). The use of 'pillar one' language led Nossal to claim that 'neither resolution invoked the Responsibility to Protect doctrine' (2013: 117). Drawing from the 'pillar one' language in the Libyan resolutions, some have argued that R2P is still too controversial for states (Hehir, 2013; Morris, 2013). Analysing patterns in the Security Council's use of R2P language - particularly in relation to the pillars - I discuss below what can be learnt about the current standing of the concept, from thematic resolutions, country-specific resolutions and voting patterns.

First, the Security Council has not shied away from 'pillar three' language altogether, and been regularly willing to use 'pillar three' language in thematic resolutions. The Security Council has included R2P language in seven thematic resolutions up to the end of 2014. Each of these has referenced paragraphs 138 and 139 
of the World Summit outcome document - including both national and international responsibilities - with the exception of Resolution 2170 on terrorism. The use of R2P language in thematic resolutions has become more frequent, with two resolutions prior to 2011 and five between 2011 and 2014. As noted above, these resolutions have also become easier and quicker to negotiate. Given that the first thematic resolution to refer to R2P took six months of intense negotiation, the later usage reflects an increased willingness for Council members to accept R2P language in resolutions, including references to 'pillar three'.

Second, as the proceeding discussion argues, the Libyan resolutions need to be understood in the context of earlier negotiations on Darfur. Resolution 1706 on Darfur and Resolution 1970 on Libya were the first two occasions when the Security Council used R2P language in country-specific resolutions. Given that innovation in resolution language can be intensely political, these early examples illustrate the limits of what was politically feasible at those points in time. Use of R2P language in Resolution 1706 which included reference to all three pillars contained in paragraphs 138 and 139 of the World Summit outcome document - was hard-won by British and French drafters. After the failure of 1706, drafters were unable to even refer to this resolution in a $2007 \mathrm{draft}$ on Darfur, even though it is standard practice to refer to previous resolutions (Author Interview, 2011b). The failure of Resolution 1706 did not make it any easier for states to advocate R2P language in resolutions. As such, when negotiating Resolution 1970, the advantages for drafters of drawing on 'previously agreed language' would likely have been outweighed by the disadvantages of associating with a failed resolution. Instead the 
language was open for re-negotiation. viii While the full details of the negotiations towards R2P language in Resolution 1970 have not yet become clear, we can see that the 'pillar one' language used in this resolution became the template for later negotiations on different crises. Indeed, between 2011 and 2014 all country-specific resolutions with R2P language have referred to the states' responsibility to protect. This chronology suggests that the use of R2P language was 'set back' by its association with Resolution 1706 on Darfur, but has since become acceptable to refer to R2P in country-specific resolutions, particularly in the form of 'pillar one'.

Third, voting patterns demonstrate that R2P language has become a broadly accepted practice for Security Council members (see Table 1). Between 2006 and 2014 there were 30 resolutions which referred to R2P. Of these three had abstentions, meaning that 27 resolutions - 90\% - had unanimous support from all fifteen Council members. This is approximately the same level of unanimous support that was achieved across all Security Council resolutions between 2000 and 2010, showing that the presence of R2P language does not counter general voting trends (Dunne and Gifkins, 2012: 523). This demonstrates that Security Council members - from all regions - are generally willing to support resolutions which include language on R2P. The three resolutions with abstentions are also telling. These were on Darfur, on Libya and on small arms and light weapons. As highlighted, Resolution 1706 on Darfur authorised a consent-based peacekeeping operation, for which there was no consent and it could not be implemented. Resolution 1973 on Libya authorised a non-consensual no-fly zone. These two are unique in Table 1 as resolutions where consent was a key issue. Given this, it is not surprising 
that the Council members who abstained on these resolutions highlighted the issue of consent (on Darfur) and pragmatic questions around the use of force (on Libya) (UN, 2006c; UN, 2011a). Unsurprisingly, issues in relation to consent and the use of force in specific crises remain the most challenging areas to find agreement (for discussion see Morris, 2016; Quinton-Brown, 2013). Similarly, Russia explained its abstention from the resolution on small arms and light weapons in pragmatic terms - that it wanted a provision condemning the supply of arms to non-state actors (UN, 2013: 4-5). This shows that there remain pragmatic questions for Security Council members on how best to implement R2P, particularly in relation to specific crises.

Analysis of these three areas - thematic resolutions, country-specific resolutions, and voting patterns - reveals a nuanced position on the acceptability of R2P for states. Since 2011 states are far more willing overall to accept R2P language in resolutions and the negotiations are less divided. As this discussion shows, language usage in resolutions is not static. Language evolves over time, and resolutions reveal a 'snapshot' of what was acceptable to Security Council members at a given point in time. In 2006 R2P language only appeared in resolutions via significant diplomatic investment from advocates. These costs decreased over time and the use of R2P language became routinized. This does not mean that it has become devoid of meaning to states, as Russia's resistance to R2P language on Syria in 2014 demonstrates. While language on R2P has become more acceptable in general - including 'pillar three' language - there is still more resistance to applying 'pillar three' language to specific crises. Pragmatic questions remain, particularly on the use of force and consent. Despite these ongoing debates on how best 
to implement R2P, Security Council members have become far more willing to include $\mathrm{R} 2 \mathrm{P}$ language in resolutions. The use of R2P language in resolutions reflects negotiations inside the Council and shows that the Council's responses to crises situations are increasingly being viewed within the context of R2P.

\section{Conclusion}

Language on R2P in Security Council resolutions has shifted from contentious to commonplace. Unlike the argument that consensus was 'lost' after the Libyan intervention, analysis of the language in Security Council resolutions shows that it became markedly easier to reference R2P after 2011 than it was before. There was intense political debate and negotiation around R2P language when it represented an innovation in the Council's use of language, but this has settled over time as acceptable 'agreed language' has been found for both thematic and country-specific resolutions. Since 2011, R2P has been regularly reaffirmed in a wide array of conflicts and thematic issues, and these drafts have become quicker and easier to negotiate. Patterns have emerged in R2P language, with thematic resolutions regularly citing both national and international responsibilities, and country-specific resolutions focusing on the language of national responsibilities. As the early negotiations highlight however, including any language on R2P was strongly resisted by some Council members in 2006. The resistance was so entrenched that a reference to R2P was removed from a draft on Darfur in 2007 and it was too difficult to explicitly cite R2P in a resolution on Somalia in 2008. This has changed. Security Council members are now more comfortable with language on R2P 
and it is accepted practice to reaffirm R2P regularly, both on national and international responsibilities. These changes indicate that the early resistance to evolution in this language has given way and R2P has settled into 'agree language' which Council members are willing to accept and regularly reaffirm.

The language in Security Council resolutions - in addition to 'insider' reports obtained from interviews, from Security Council Report, and via WikiLeaks - shows that R2P was highly contentious but over time has become a regular feature of the internal deliberations within the Security Council. While this article has focused on resolutions, it is worth noting that the same pattern holds for presidential statements made by the Security Council. The Council has used R2P in presidential statements more regularly from 2011, both in statements on specific countries and in statements on thematic issues (Global Centre for the Responsibility to Protect, 2014a). Situated as one aspect of the broader normative shift towards R2P, as evidenced by Bellamy (2015) and Glanville (2016), we can see the Security Council becoming increasingly engaged in Welsh's 'responsibility to consider’ (2013). Via the advocacy of Council members which support $\mathrm{R} 2 \mathrm{P}$, it has become accepted practice for R2P to be one aspect of the negotiations when drafting resolutions and statements. Over time we can see R2P becoming a standard element of the internal negotiations within the Council and part of the way the Council frames its responses to crisis situations and thematic issues.

\section{References}

Adler E and Pouliot V (2011) International practices. International Theory 3: 1-36. 
Author Interview (2011a) Interview with an official involved in the negotiations. 9 September, Copenhagen.

Author Interview (2011b) Interview with UN source on Darfur. 25 August, London. Author Interview (2011c) Interview with US State Department official. 15 February, New York.

Author Interview (2012) Interview with an official involved in the negotiations. 28 March, telephone interview.

Badescu CG and Weiss TG (2010) Misrepresenting R2P and advancing norms: An alternative spiral? International Studies Perspectives 11: 354-374.

Bellamy AJ (2011a) Global Politics and the Responsibility to Protect: From words to deeds. London and New York: Routledge.

Bellamy AJ (2011b) Libya and the Responsibility to Protect: The exception and the norm. Ethics and International Affairs 25: 263-269.

Bellamy AJ (2014) From Tripoli to Damascus? Lesson learning and the implementation of the Responsibility to Protect. International Politics 51(1): 23-44. Bellamy AJ (2015) The Responsibility to Protect: A Defence, Oxford: Oxford University Press.

Bellamy AJ and Williams PD (2011) The new politics of protection? Cote d'Ivoire, Libya and the Responsibility to Protect. International Affairs 87(4): 845-870. Brown C (2003) Selective humanitarianism: In defence of inconsistency. In Ethics and Foreign intervention, eds. DK Chatterjee and DE Scheid. Cambridge: Cambridge University Press. 
Chesterman S (2011) 'Leading from behind': The Responsibility to Protect, the Obama Doctrine, and humanitarian intervention after Libya. Ethics and International Affairs 25(3): 279-285.

Cronogue G (2012) Responsibility to protect: Syria the law, politics and future of humanitarian intervention post-Libya. International Humanitarian Legal Studies 3(1): 124-159.

Dunne T and Gifkins J (2011) Libya and the state of intervention. Australian Journal of International Affairs 65(5): 515-529.

Evans G (2004) Darfur: The world should be ready to intervene in sudan. New York Times, 15 May.

Evans G (2012) The Responsibility to Protect after Libya and Syria. Available at http://www.gevans.org/speeches/speech476.html (accessed 20 July 2014).

Fierke KM (2002) Links across the abyss: language and logic in International Relations. International Studies Quarterly 46: 331-354.

Gifkins J (2012) The UN Security Council divided: Syria in crisis. Global Responsibility to Protect 4(3): 377-393.

Gifkins J (2013) Inside the UN Security Council: The Influence of the Social Environment on Decision Making PhD Dissertation, School of Political Science and International Studies. University of Queensland.

Glanville L (2013) Intervention in Libya: from sovereign consent to regional consent. International Studies Perspectives 14: 325-342. 
Glanville L (2016) Does R2P matter? Interpreting the impact of a norm. Cooperation and Conflict, 51(2).

Global Centre for the Responsibility to Protect (2014a) R2P references in United Nations Security Council resolutions and presidential statements. Available at: http://s156658.gridserver.com/media/files/unsc-resolutions-and-statementswith-r2p-table-as-of-august-2014.pdf (accessed 5 September 2014).

Global Centre for the Responsibility to Protect (2014b) Summary of the Sixth Informal Interactive Dialogue of the UN General Assembly on the Responsibility to Protect, held on 8 September 2014. Available at: http://www.globalr2p.org/media/files/summary-of-the-r2p-dialogue-2014.pdf (accessed 24 September 2014).

Hamilton R (2011) Fighting for Darfur: Public Action and the Struggle to Stop Genocide. New York: Palgrave Macmillan.

Hehir A (2013) The permanence of inconsistency: Libya, the Security Council, and the Responsibility to Protect. International Security 38: 137-159.

Hehir A (2016) Assessing the influence of the Responsibility to Protect on the UN Security Council during the Arab Spring. Cooperation and Conflict, 51(2). Holt V, Taylor G and Kelly M (2009) Protecting civilians in the context of UN peacekeeping operations: Successes, setbacks and remaining challenges. New York: United Nations.

Loiselle M-E (2013) The normative status of the Responsibility to Protect after Libya. Global Responsibility to Protect 5(3): 317-341. 
Lynch C (2010) The 10 worst UN Security Council resolutions ever. Foreign Policy, 21 May. Available at http://foreignpolicy.com/2010/05/21/the-10-worst-u-n-securitycouncil-resolutions-ever-2/

Morris J (2013) Libya and Syria: R2P and the spectre of the swinging pendulum. International Affairs 89(5): 1265-1283.

Morris J (2016) The Responsibility to Protect and the use of force: Remaking the procrustean bed? Cooperation and Conflict, 51(2).

Neumann IB (2007) “A speech that the entire Ministry may stand for,” or: Why diplomats never produce anything new. International Political Sociology 1(2): 183200.

Nossal, KR (2013) The use - and misuse - of R2P: The case of Canada. In Hehir A and Murray R (eds) Libya, the Responsibility to Protect and the Future of Humanitarian Intervention. Basingstoke: Palgrave Macmillan.

Quinton-Brown P (2013) Mapping dissent: The Responsibility to Protect and its state critics. Global Responsibility to Protect 5: 260-282.

Security Council Report (2005) December monthly forecast. Available at: http://www.securitycouncilreport.org/atf/cf/\%7B65BFCF9B-6D27-4E9C-8CD3CF6E4FF96FF9\%7D/SCR_ForecastDec2005.pdf (accessed 1 September 2014). Security Council Report (2006a) Update report on the protection of civilians in armed conflict, 13 January. Available at: http://www.securitycouncilreport.org/atf/cf/\%7B65BFCF9B-6D27-4E9C-8CD3- 
CF6E4FF96FF9\%7D/Update\%20Report\%2013\%20January\%202006_POC.pdf (accessed 1 September 2014).

Security Council Report (2006b) Update report on the protection of civilians in armed conflict, 21 June. Available at:

http://www.securitycouncilreport.org/atf/cf/\%7B65BFCF9B-6D27-4E9C-8CD3-

CF6E4FF96FF9\%7D/Update\%20Report\%2021\%20June\%202006_PoC.pdf (accessed 1 September 2014).

Security Council Report (2006c) Update report on the protection of civilians in armed conflict, 8 March. Available at:

http://www.securitycouncilreport.org/atf/cf/\%7B65BFCF9B-6D27-4E9C-

8CD3-CF6E4FF96FF9\%7D/Update\%20Report\%208\%20March\%202006_POC.pdf (accessed 1 September 2014).

Security Council Report (2007) Update report on the protection of civilians in armed Conflict, 18 June. Available at: http://www.securitycouncilreport.org/updatereport/lookup-c-glKWLeMTIsG-b-2821453.php (accessed 2 June 2015).

Security Council Report. (2008) Security Council action under Chapter VII: Myths and realities. No. 1, 23 June. Available at:

http://www.securitycouncilreport.org/special-research-report/lookup-cglKWLeMTIsG-b-4202671.php (accessed 4 June 2015).

Security Council Report (2013a) Council to adopt first resolution on small arms. What's in Blue. Available at: http://www.whatsinblue.org/2013/09/council-to-adopt-first-everthematic-resolution-on-small-arms.php (accessed 5 September 2014). 
Security Council Report (2013b) Sudan-South Sudan consultations and mission in South Sudan renewal. What's in Blue. Available at:

http://www.whatsinblue.org/2013/07/sudan-south-sudan-consultations-and-mission-insouth-sudan-renewal.php (accessed 5 September 2014).

Security Council Report (2014a) Possible vote on Syria draft humanitarian resolution. What's in Blue. Available at: http://www.whatsinblue.org/2014/02/possible-vote-onsyria-draft-humanitarian-resolutiontomorrow.php (accessed 5 September 2014). Security Council Report (2014b) Prevention and fight against genocide briefing. What's in Blue. Available at: http://www.whatsinblue.org/2014/04/prevention-and-fightagainst-genocide-briefing.php (accessed 5 September 2014).

Strauss E (2009) A bird in the hand is worth two in the bush - on the assumed legal nature of the Responsibility to Protect. Global Responsibility to Protect 1(3): 291-323.

Stromseth JE (1993) Iraq's repression of its civilian population. In Damrosch LF (ed) Enforcing restraint. New York: Council on Foreign Relations Press.

Thakur R (2013) R2P After Libya and Syria: Engaging emerging powers. The Washington Quaterly 36(2): 61-76.

United Nations (2004a) 5040th meeting of the Security Council. New York, 18 September, S/PV.5040.

United Nations (2004b) 5082nd meeting of the Security Council. New York, 19 November, S/PV.5082.

United Nations (2004c) Security Council Resolution 1564. New York, 18 September, 
S/RES/1564.

United Nations (2004d) 'Risk of genocide remains frighteningly real', Secretary-

General tells Human Rights Commission as he launches Action Plan to Prevent

Genocide. Geneva, 7 April, SG/SM/9245.

United Nations (2004e) Security Council Resolution 1574. New York, S/RES/1574.

United Nations (2006a) 5359th meeting of the Security Council. New York, 27

January, S/PV.5359.

United Nations (2006b) 5359th meeting of the Security Council (Resumption 1). New

York, 27 January, S/PV.5359.

United Nations (2006c) 5519th meeting of the Security Council. New York, 31 August, S/PV.5519.

United Nations (2006d) Security Council Resolution 1674. New York, 28 April, S/RES/1674.

United Nations (2006e) Security Council Resolution 1706. New York, 31 August, S/RES/1706.

United Nations (2006f) Security Council Resolution 1653. New York, 27 January, S/RES/1653.

United Nations (2007) Security Council Resolution 1769. New York, 31 July, S/RES/1769.

United Nations (2009) Security Council Resolution 1894. New York, 11 November, S/RES/1894.

United Nations (2011a) 6498th meeting of the Security Council. New York, 17 March, 
S/PV.6498.

United Nations (2011b) 6627th meeting of the Security Council. New York, 4 October, S/PV.6627.

United Nations (2011c) Draft Security Council Resolution. New York, 4 October, S/2011/612.

United Nations (2011d) Security Council Resolution 1970. New York, 26 February, S/RES/1970.

United Nations (2011e) Security Council Resolution 1973. New York, 17 March, S/RES/1973.

United Nations (2013) 7036th meeting of the Security Council. New York, 26 September, S/PV.7036.

United Nations (2014a) 7116th meeting of the Security Council. New York, 22 February, S/PV.7116.

United Nations (2014b) Security Council Resolution 2150. New York, 16 April, S/RES/2150.

Weiss TG (2014) Military humanitarianism: Syria hasn't killed it. The Washington Quaterly 37(1): 7-20.

Welsh J (2013) Norm contestation and the Responsibility to Protect. Global Responsibility to Protect 5: 365-396.

Wheeler N (2000) Saving Strangers. Oxford: Oxford University Press. WikiLeaks (2006) UNSC/Darfur: Council inching toward adoption of draft resolution. 
Available at:

https://www.wikileaks.org/plusd/cables/06USUNNEWYORK1660_a.html (accessed 21 September 2012).

WikiLeaks (2007) AU/UN Hybrid in Darfur: Narrowing Differences. Available at: https://wikileaks.org/cable/2007/07/07USUNNEWYORK563.html\# (accessed 26 September 2012).

Williams PD and Bellamy AJ (2005) The Responsibility to Protect and the crisis in darfur. Security Dialogue 36(1): 27-47.

Wood MC (1998) The interpretation of Security Council resolutions. In: Frowein JA and Wolfrum R (eds) Max Planck yearbook of United Nations law. London: Kluwer Law International, pp. 73-95.

Yamashita H (2007) Reading 'threats to international peace and security' 1946-2005. Diplomacy and Statecraft 18: 551-572.

Table 1: R2P language in UN Security Council Resolutions 2006-2014

\begin{tabular}{|l|l|l|l|l|}
\hline Topic & Date & Resolut & R2P & Vote \\
& & ion & Responsibilities* & \\
\hline
\end{tabular}




\begin{tabular}{|c|c|c|c|c|}
\hline $\begin{array}{l}\text { The Great Lakes } \\
\text { region }\end{array}$ & 27 January 2006 & 1653 & State & Unanimous \\
\hline $\begin{array}{l}\text { The protection of } \\
\text { civilians in armed } \\
\text { conflict }\end{array}$ & 28 April 2006 & 1674 & $\begin{array}{l}\text { State and } \\
\text { international }\end{array}$ & Unanimous \\
\hline Darfur & 31 August 2006 & 1706 & $\begin{array}{l}\text { State and } \\
\text { international }\end{array}$ & $\begin{array}{l}\text { China, Qatar and } \\
\text { Russia abstained }\end{array}$ \\
\hline $\begin{array}{l}\text { The protection of } \\
\text { civilians in armed } \\
\text { conflict }\end{array}$ & 11 November 2009 & 1894 & $\begin{array}{l}\text { State and } \\
\text { international }\end{array}$ & Unanimous \\
\hline Libya & 26 February 2011 & 1970 & State & Unanimous \\
\hline Libya & 17 March 2011 & 1973 & State & $\begin{array}{l}\text { Brazil, China, } \\
\text { Germany, India and } \\
\text { Russia abstained }\end{array}$ \\
\hline Cote d'Ivoire & 30 March 2011 & 1975 & State & Unanimous \\
\hline South Sudan & 08 July 2011 & 1996 & State & Unanimous \\
\hline Yemen & 21 October 2011 & 2014 & State & Unanimous \\
\hline Libya & 27 October 2011 & 2016 & State & Unanimous \\
\hline Libya & 12 March 2012 & 2040 & State & Unanimous \\
\hline South Sudan & 05 July 2012 & 2057 & State & Unanimous \\
\hline Mali & 20 December 2012 & 2085 & State & Unanimous \\
\hline Somalia & 06 March 2013 & 2093 & State & Unanimous \\
\hline
\end{tabular}




\begin{tabular}{|c|c|c|c|c|}
\hline Libya & 14 March 2013 & 2095 & State & Unanimous \\
\hline Mali & 25 April 2013 & 2100 & State & Unanimous \\
\hline South Sudan & 11 July 2013 & 2109 & State & Unanimous \\
\hline $\begin{array}{l}\text { Small arms and } \\
\text { light weapons }\end{array}$ & 26 September 2013 & 2117 & $\begin{array}{l}\text { State and } \\
\text { international }\end{array}$ & Russia abstained \\
\hline $\begin{array}{l}\text { Central African } \\
\text { Republic }\end{array}$ & 10 October 2013 & 2121 & State & Unanimous \\
\hline $\begin{array}{l}\text { Central African } \\
\text { Republic }\end{array}$ & 05 December 2013 & 2127 & State & Unanimous \\
\hline $\begin{array}{l}\text { Central African } \\
\text { Republic }\end{array}$ & 28 January 2014 & 2134 & State & Unanimous \\
\hline Syria & 22 February 2014 & 2139 & State & Unanimous \\
\hline $\begin{array}{l}\text { Central African } \\
\text { Republic }\end{array}$ & 10 April 2014 & 2149 & State & Unanimous \\
\hline $\begin{array}{l}\text { The prevention } \\
\text { and fight against } \\
\text { genocide }\end{array}$ & 16 April 2014 & 2150 & $\begin{array}{l}\text { State and } \\
\text { international }\end{array}$ & Unanimous \\
\hline South Sudan & 27 May 2014 & 2155 & State & Unanimous \\
\hline Syria & 14 July 2014 & 2165 & State & Unanimous \\
\hline Terrorism & 15 August 2014 & 2170 & State & Unanimous \\
\hline $\begin{array}{l}\text { The prevention of } \\
\text { armed conflict }\end{array}$ & 21 August 2014 & 2171 & $\begin{array}{l}\text { State and } \\
\text { international }\end{array}$ & Unanimous \\
\hline
\end{tabular}




\begin{tabular}{|l|l|l|l|l|}
\hline Peacekeeping & 20 November 2014 & 2185 & State and & Unanimous \\
\hline South Sudan & 25 November 2014 & 2187 & State & Unanimous \\
\hline
\end{tabular}

Compiled from: United Nations Security Council Meetings Records. Available at: http://www.un.org/en/sc/meetings/

* Refers to the language on R2P and whether it is framed around state or international responsibilities. Reference to paragraph 139 of the 2005 World Summit outcome document is counted as 'international'.

\footnotetext{
${ }^{\mathrm{i}}$ An earlier version of this article was presented as part of the ESRC Seminar Series on Intervention and R2P. Many thanks to Stephen McLoughlin, Alex Bellamy, Miriam Cullen, Holger Niemann, Bastian Loges, James Pattison and two anonymous reviewers for discussions and helpful comments on an earlier draft. I would also like to thank the guest editors for this special issue.

ii For comprehensive analysis on when Security Council resolutions are binding, see Security Council Report (2008).

iii Notable exceptions to this are Wood (1998) which discusses how to interpret the language used in Security Council resolutions; and Holt et al (2009) which analyses the evolution of language on the protection of civilians.

iv Although Neumann's analysis is primarily in relation to drafting speeches for the Norwegian Foreign Ministry, he argues that his analysis is congruent with other the drafting processes for other foreign policy documents and in other country contexts.

v Here I mean 'precedent' in a political sense rather than a legal sense. The Security Council is a political body and members choose to use previously agreed language, without legal obligation.

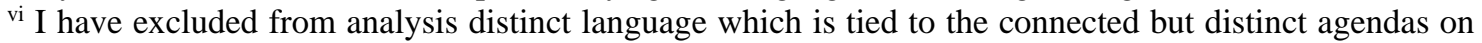
the Protection of Civilians and on Women Peace and Security, which use the phrases 'protect civilians under imminent threat of physical violence' and 'parties to armed conflicts bear the primary responsibility to ensure the protection of affected civilians' respectively.

vii Additionally, between 2001 and 2005 there were eight Security Council resolutions on the conflict within Georgia which used the phrase 'responsibility to protect returnees'. The use of this phrase stopped after the 2005 World Summit, however like others, I have not found any evidence to link this language to the ICISS version of R2P (Chesterman, 2011: 2-3). The change in language after the World Summit agreement may have been coincidental.

viii For example, while Resolution 1970 recalled 'the Libyan authorities' responsibility to protect its population' an earlier draft added 'under any circumstances'. See 'UN SC Draft on Libya and list of sanctioned names', Al Arabiya News, 26 February 2011, available at

http://www.alarabiya.net/articles/2011/02/26/139380.html
} 